\title{
A linguagem cinematográfica como linguagem cotidiana ${ }^{1}$
}

\section{Cinematographic language as everyday language}

\author{
Roger Odin ${ }^{2}$ \\ Traduzido por Eduardo Paschoa/ ${ }^{3}$
}

Professor emérito em Ciências da Comunicação na Université Paris 3 - Sorbonne Nouvelle, onde dirigiu o Instituto de Pesquisa em Cinema e Audiovisual (Ircav, na sigla em francês), de 1983 a 2003. Teórico de tradição semiopragmática, publicou inúmeras obras, todas inéditas no Brasil: Cinéma et production de sens (A. Colin, 1990); De la fiction (De Boeck, 2000); e a mais recente Les espaces de communication (PUG, 2011), em que detalha a teoria e o método semio-pragmático. Odin se dedica ao cinema documentário, às produções amadoras e ao celular. Ele dirige, ao lado de L. Allard e L. Creton, o grupo de pesquisa Mobiles et création, no Ircav, e já publicou coletivamente as obras (inéditas no Brasil): Téléphone mobile et création, em colaboração com L. Allard e L. Creton (A. Colin, 2014); e Arts et mobiles, também em colaboração com os mesmos pesquisadores (coleção Théorème, Presses de la Sorbonne Nouvelle, 2017). Esteve no Brasil pela última vez em 2018, ocasião em que ministrou alguns seminários na Universidade Estadual de Campinas (Unicamp). E-mail: semio.prag@wanadoo.fr. Artes da Universidade de São Paulo (ECA-USP). Bolsista Fapesp, realizou estágio doutoral na Universidade Sorbonne Nouvelle - Paris 3 (2019-2020). Membro dos grupos de pesquisa MidiAto (USP) e Rede Metacrítica de Pesquisa em Cultura Midiática. E-mail: eduardopaschoals@gmail.com. 


\section{Resumo}

Este artigo mostra como o celular ou, mais precisamente, o smartphone, permitiu, pela primeira vez na história do cinema, a instauração da linguagem cinematográfica como linguagem cotidiana, ou seja, como operador no espaço da comunicação cotidiana. Para isso, colocamos em evidência as principais funções dessa linguagem nesse espaço, analisamos sua forma e nos interrogamos sobre as consequências dessa mudança de status.

\section{Palavras-chave}

Linguagem cinematográfica, audiovisual, comunicação, semiopragmática.

\section{Abstract}

This article shows how the cell phone, or more precisely, the smartphone, allowed, for the first time in the history of cinema, the establishment of cinematographic language as an everyday language, that is, as an operator in the space of everyday communication. For this purpose, we highlight the main functions of this language in this space, analyze its form, and reflect about the consequences of this status change.

\section{Keywords}

Cinematographic language, audiovisual, communication, semiopragmatics. 


\section{Introdução}

Por algumas vezes, exprimi a ideia de que seria necessário separar a teoria do cinema daquela da linguagem cinematográfica (ODIN, 2012a, 2012b). Hoje, sugiro reformular essa proposição, dizendo que é necessário conceber a teoria da linguagem cinematográfica levando em consideração os diferentes espaços de comunicação nos quais ela intervém (ODIN, 2011). A linguagem cinematográfica, na verdade, emergiu sempre em múltiplos espaços de comunicação (espaço do filme pedagógico, científico, médico, industrial, publicitário, de família etc.), e o espaço de comunicação "cinema" era apenas mais um deles. Hoje, esse fenômeno assume uma escala inédita, mas o que mais nos chama atenção - e com certeza o que é mais surpreendente - é a inscrição da linguagem cinematográfica como operadora no espaço da comunicação cotidiana4.

Chamo de espaço da comunicação cotidiana o espaço das interações com intenção comunicativa que ocorrem entre pessoas comuns (inclusive entre si mesmo) sobre ações comuns da vida cotidiana (ou da própria vida).

A linguagem verbal, a linguagem escrita e a linguagem gestual foram, desde sempre, as grandes operadoras desse espaço. Mais recentemente, acrescentouse a fotografia, cuja presença se ampliou consideravelmente desde a passagem ao digital. Quanto à linguagem cinematográfica, ela está bem atrás, como nota André Gunthert: "inúmeros teóricos esperavam que a chegada de novas ferramentas visuais fosse acompanhada de um deslocamento em direção à imagem animada, mais atrativa, e por uma desafeição à imagem estática. A prática do vídeo amador certamente teve um importante progresso. Mesmo assim, a imagem fixa continua a ser, de longe, o conteúdo mais compartilhado" (GUNTHERT, 2015, p. 135).

Por que, então, dedicar um artigo a esse tema? A resposta é simples: mesmo que, comparada à fotografia, a linguagem cinematográfica esteja pouco 
presente no espaço da comunicação cotidiana, cada vez mais, ela se torna parte do nosso dia a dia. É essa emergência insistente que me interessa aqui. De fato, o número de produções audiovisuais presentes nesse espaço surgem de modo impressionante. Não dispomos, infelizmente, de estatísticas específicas a esse campo, mas sabemos que mais de 6 bilhões de horas de vídeo são assistidas a cada mês e que mais de 100 horas de conteúdo em vídeo são colocadas a cada minuto no YouTube. Certamente que nem todos esses vídeos tratam de um espaço cotidiano, assim como, inversamente, nem todos os vídeos feitos nesse espaço são publicados nas redes sociais: muitos deles são consumidos no próprio local, ao vivo, e não figuram, portanto, nessas estatísticas.

E então, não posso deixar de me impressionar: quem poderia dizer, há alguns anos apenas, que eu poderia trocar com amigos, em uma mesa de um café, vídeos das nossas férias? Quem diria que a linguagem cinematográfica me ajudaria um dia a utilizar o papel de parede que eu acabara de comprar, ao filmar no meu telefone celular uma demonstração que estava disponível em uma tela no stand onde fiz as compras? Quem diria que a linguagem cinematográfica me permitiria mostrar, ao vivo, cômodo por cômodo, aos membros da família mais distantes, o novo apartamento que acabei de comprar? Esses são apenas alguns dos exemplos. Meu objetivo é desdobrar os processos que os tornaram possíveis.

No Ensaio sobre os princípios de uma filosofia do cinema, Gilbert CohenSéat elaborou bem o ponto de partida: "o filme como meio de comunicar alguma coisa que procuramos exprimir é utilizado, na emissão, apenas por um número relativamente ínfimo de indivíduos especializados, que qualificamos corretamente de profissionais. O que o filme comunica é recebido, por outro lado, por massas incontáveis e díspares, renovadas constantemente" (COHEN-SÉAT, 1958, p. 148). Essa assimetria fundamental afasta radicalmente a linguagem cinematográfica do espaço da comunicação cotidiana. No entanto, muito rápido, com o cinema amador e sobretudo com o filme de família, o cinema tentou se reaproximar do espaço da comunicação cotidiana. 


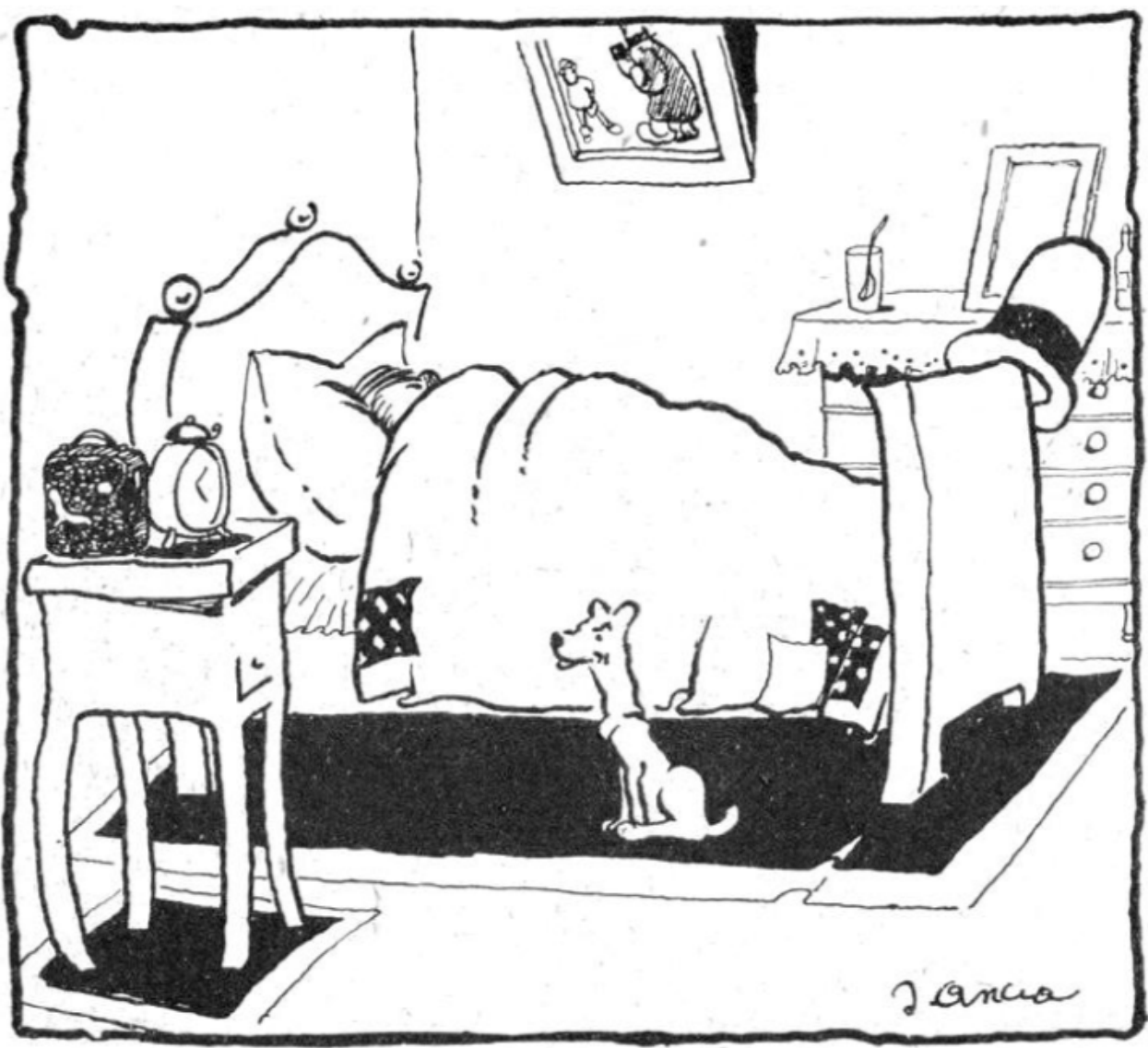

LA CARICATURE ET LE "PATHE-BABY »

- Comment, M. Papouf ne s'éveille pas ?

- Il aura encore une fois remonté son "Pathé-Baby" au lieu de son réveil.

Figura 1: "A caricatura e o 'Pathé-baby"'

A pergunta: "- Como o Sr. Papouf não acorda?" e a resposta: "Ele deve ter mais uma vez apertado seu "Pathé-Baby" no lugar de seu despertador".

Fonte: Le Cinéma chez soi (1930, n. 41).

O sentido dessa ilustração ${ }^{5}$ (Figura 1) é claro: a câmera Pathé é tão bem integrada quanto um despertador ao espaço cotidiano, ao ponto de podermos confundir os dois objetos. A realidade, no entanto, é outra: mesmo se Pathé fez grandes esforços para tornar seu material de $9.5 \mathrm{~mm}$ acessível - "hoje em dia, por mobiliário em um seminário conjunto entre a Universidade de Montréal e a Universidade Paris 3, em março de 2017. 
entrar nas nossas casas, ele se tornou pequeno, simples e barato", diz o Catalogue général Pathé-Baby, de 1923 - é somente com o 8 mm (1932) e sobretudo com o Super 8 (1965) que a situação começaria a evoluir. Mas é necessário constatar que a acessibilidade resta ainda muito limitada se nos referirmos ao conjunto da população. De outros pontos de vista, como produção realizada no espaço cotidiano por pessoas comuns, para outras pessoas comuns, o filme de família tem todos os sinais de pertencimento ao espaço de comunicação cotidiana. Mas não podemos confiar nas aparências. Na realidade, não há nada de menos cotidiano que o fato de tirar sua câmera para filmar sua família; por um lado, isso só se faz em espaços-tempos bem específicos: aniversários, reuniões de família, cerimônias, férias, viagens. Por outro, o próprio filme de família não reflete em nada a vida cotidiana da família: ele revela sobretudo uma construção de arquétipos ou de imagens míticas fundamentalmente eufóricas. Enfim, a projeção de um filme de família é sempre um evento excepcional e ritualizado: nós o compartilhamos na celebração da família. No fim das contas, no filme de família não há nada do espaço de comunicação cotidiana (ODIN, 1995).

A chegada da televisão e do vídeo modifica consideravelmente a situação. As produções passaram a ser vistas na sala de estar ou na sala de jantar, a relação com a linguagem cinematográfica é integrada ao cotidiano e é inscrita em uma lógica de fluxo, um fluxo ao qual nós temos acesso potencialmente o tempo todo. Esse fenômeno se acentua ainda mais com a neo-televisão, que pudemos descrever como "um espaço de vida, ao menos se o compreendermos como um espaço onde, de uma parte e de outra da tela, há pessoas que passam horas e horas de suas vidas" (CASETTI; ODIN, 1990, p. 17). Da mesma maneira, em oposição ao filme de família, os vídeos familiares não hesitam em mostrar a vida cotidiana "como ela é", com suas tensões, seus problemas e até seus dramas (ODIN, 1999).

Mas, mais que isso, a televisão se mostrou uma excelente professora de linguagem cinematográfica. As noções de plano fechado, de panorâmica, de travelling, de montagem etc., entraram no vocabulário da comunicação cotidiana; conhecemos a famosa frase de François Truffaut, "hoje em dia, todo mundo tem 
dois trabalhos: o seu e o de crítico de cinema". Nessa fase, podemos dizer que todo mundo adquiriu uma competência (mais ou menos) explícita em linguagem cinematográfica, mas não se trata ainda de uma competência ativa, que nos permitiria usá-la para nos comunicar. Certamente, com o vídeo, pessoas comuns que utilizaram a linguagem cinematográfica na produção se tornaram cada vez mais numerosas, mas os números restavam ainda extremamente modestos. Por exemplo, na França, em 1993, segundo Laurent Creton (1995), a taxa de equipamento de filmagem na população não passava de 12,5\%. Na realidade, é apenas com a chegada do telefone celular e, mais precisamente, dos smartphones, que as coisas começaram realmente a mudar.

\section{Smartphone e a linguagem cinematográfica}

O smartphone pode ser considerado como o agente que permitiu a instauração da linguagem cinematográfica como linguagem cotidiana7. Segundo o escritório Strategy Analytics, o número de usuários de smartphones chegou, hoje em dia, aos 2,1 bilhões, e pode-se prever que $81 \%$ dos celulares comercializados em 2020 serão smartphones. "Há um sentido em que o quantitativo se torna qualitativo", nota o filósofo Maurizio Ferraris (2006, p. 107), em uma obra dedicada precisamente ao telefone portátil. A consequência dessa inacreditável difusão é colocar à disposição de quase todo mundo, de uma só vez, uma tela que permite assistir às produções em linguagem cinematográfica e uma câmera que permite gravar imagens estáticas ou animadas. O primeiro efeito do celular é tanto de resolver o problema da acessibilidade quanto de expandir a uma utilização ativa da linguagem cinematográfica que a torna possível a todo tempo e em todos os lugares, o que é precisamente uma definição de espaço cotidiano.

Essa nova disponibilidade levou o jornalista Didier Péron a declarar que hoje em dia "todo mundo tem dois trabalhos, o seu e o de cineasta" (PÉRON, 2011

Hoje em dia, o funcionamento da linguagem cinematográfica como linguagem cotidiana passa igualmente pelos tablets e phablets (telefones com telas maiores), mas como trato aqui da emergência desse processo, suas utilizações não são analisadas. 
apud GAUDREAULT; MARION, 2013, p. 88). Podemos notar o jogo de palavras com a fórmula de Truffaut, mas é necessário reconhecer que isso não dá conta do que ocorre, pois, precisamente, a novidade é que a maior parte daqueles que utilizam a linguagem cinematográfica não se comportam de maneira alguma como cineastas, mas como homens comuns - mesmo que essa pessoa tenha, fora dessa situação, a profissão de cineasta. Algo como o homem a quem JeanLouis Schefer (1980) dá voz, o homem comum do qual trato aqui se caracteriza por sua falta de especialização, de qualificação e de pretensão: é um homem sem qualidades. O que me interessa aqui é o momento em que passamos a nos comunicar pela linguagem cinematográfica sobre "coisas em comum", sobre o que acontece quando nada acontece, sobre "o que acontece a cada dia e que volta todo dia, o banal, o cotidiano, o evidente, o comum, o ordinário, o que está aquém do ordinário, o ruído de fundo, o habitual", segundo as palavras de Georges Perec (1975, p. 251-255) em "Approche de quoi".

O celular também permite arquivar as produções em linguagem cinematográfica, seja diretamente na memória do aparelho, seja em uma memória externa (como a Nuvem). O que até então não era possível com a fita magnética ou com o computador, tornou-se possível em todo lugar. As produções em linguagem cinematográficas se encontram de tal modo dispersas em um espaço-tempo indefinido, a priori infinito (mesmo que saibamos bem que o armazenamento não durará indefinidamente), uma espécie de terra de ninguém indeterminada, uma forma de espaço cotidiano permanente, onde são acessíveis a todo momento (ODIN, 2015).

O celular, enfim, leva à linguagem cinematográfica formas de interatividade que permitirão à linguagem cinematográfica se comportar como linguagem de comunicação cotidiana: o que as conduz a situações de partilha. O fato de hoje em dia todos os celulares estarem conectados abre essa possibilidade. Posso, por exemplo, enviar a qualquer momento, em qualquer lugar, aos membros mais distantes da minha família ou aos meus amigos, pequenas sequências de minha vida cotidiana. Isso se tornou tão comum que esquecemos tudo o que era preciso fazer antes para executar a mesma operação, mesmo no tempo do 
vídeo: uma vez que gravávamos o vídeo, era necessário entrar em nossas casas, eventualmente fazer uma cópia da fita cassete, embalá-la, ir até os correios, ficar na fila, pagar para colocar um selo e, depois, no que diz respeito ao destinatário, aguardar a chegada da encomenda, eventualmente ir até à agências dos correios para receber o pacote, voltar a sua casa para colocar a fita no vídeo cassete e assisti-la na televisão; agora, apenas um clique e o compartilhamento está feito (e eu mantenho o original sem ter feito sequer uma cópia). Outra maneira de troca: subir um vídeo em um site em acesso livre. Essa forma é totalmente nova e, ao mesmo tempo, ela se tornou completamente comum: milhões de vídeos são colocados online todos os dias.

Mas ainda há mais: o celular permitiu a passagem da interatividade à interação, quer dizer, a um modo de interatividade que envolve dois ou mais sujeitos que utilizam a linguagem cinematográfica para trocar. Essa transformação é essencial para o espaço da comunicação cotidiana, que é fundamentalmente um espaço de relações interpessoais. Notaremos que eu falo de troca entre indivíduos; é porque, com o celular, nós estamos sob o emblema da enunciação pessoal: a referência ao autor do vídeo é imediata. Isso ocorre mesmo no caso dos vídeos que nós não gravamos, mas que compartilhamos: na frase "eu acabei de receber de tal pessoa Um dia no campo"," "tal pessoa" não é Jean Renoir, mas o responsável pelo envio. As produções filmadas com o celular dizem "EU".

Gostaria agora de insistir na forma de interação que é, sem dúvida, a mais comum no espaço de comunicação cotidiana: a conversa. Sempre falamos muito sobre as produções audiovisuais (em particular quando das sessões de projeção dos filmes de família), e o fazemos cada vez mais, porém é necessário distinguir quando falamos sobre as imagens de quando conversamos com as imagens. Lembremos que, para Christian Metz (1991), a própria noção de conversa audiovisual só poderia ser metafórica e que Gianfranco Bettetini (1984), que consagrou a ela a obra La conversazione audiovisiva, fala de conversa "fantasmática". De fato, 
para que haja conversa, é necessário que haja interlocução, ou seja, dois Sujeitos que se comuniquem sobre um mesmo eixo, com a permutação dos papéis de emissor e de receptor (na conversa, os actantes respondem uns aos outros). Portanto, era, até então, uma situação que a linguagem cinematográfica não permitia. Se a conversa audiovisual se tornou possível hoje em dia, é porque, com o celular, os Sujeitos podem trocar por meio da linguagem cinematográfica, se comportando alternadamente como EU e como VOCE.

No entanto, nós não seríamos capazes de equiparar a conversa audiovisual à conversa verbal. Seria necessário analisar em detalhes os pontos de aproximação e de diferença ${ }^{9}$. Vou me contentar em apontar alguns deles. Comecemos pelo recorte espaço-temporal. Sabemos, por meio dos linguistas, que a situação normal é a conversa face a face. É tentador pensar que a troca de vídeos face a face (por exemplo, via Bluetooth), como ocorre muitas vezes em uma mesa de café, em sua casa, ou na praia, corresponde a esse modelo, porém, não estamos no mesmo esquema comunicacional: os vídeos, mesmo se contribuam à inter-relação, mesmo se respondem uns aos outros, não são mais que uma parte da conversa cuja circunstância é, em geral, conduzida pela linguagem verbal. Um outro tipo é a conversa à distância, por meio de vídeos interpostos. Aqui, estamos em um tipo de troca de correspondências fácil e rápida, e às vezes tão rápida que a troca se assemelha em muito ao ritmo da conversa oral, mas não há o face a face. Logo, apenas a conversa ao vivo à distância (como por Skype, por exemplo) conserva a situação da conversa face a face (e é esse seu maior atrativo em relação à conversa telefônica) e tudo o que acompanha isso: o papel do visual (contexto, gestual), a troca de olhares, o trabalho de adaptação permanente dos locutores um com o outro, a coprodução do discurso. Mas ainda assim há diferenças: a linguagem cinematográfica assegura a encenação da conversa, mas a própria conversa se dá, em grande parte, pela via oral; muitas vezes, ocorre de o que é mostrado 
no vídeo ser mais importante do que o que se diz (por exemplo, mostrar o bebê que acabou de nascer).

Vejamos agora o funcionamento dos turnos linguísticos. A estrutura mais frequente é do tipo "estímulo-resposta" (falamos em "pares adjacentes"). É totalmente possível começar uma conversa por um vídeo, basta que ele seja suficientemente intrigante, belo ou provocante para suscitar reações. É um fenômeno constante nas redes sociais. De fato, é bastante raro que um vídeo postado em um site ou em um blog não provoque nenhuma reação; ela se dá, geralmente, por uma mensagem escrita, mas a resposta pode ser feita por meio de um ou muitos vídeos: um amigo que publicou um vídeo sobre as flores de seu jardim, viu também aparecer em seu Facebook inúmeros vídeos de flores, com comentários do tipo: "minhas margaridas estão mais bonitas que as suas!", "por que não há rosas?", "eu prefiro frutas a flores" (plano fechado de alguém que se deleitava comendo as cerejas que acabara de colher sob a árvore), "eu detesto flores" (vídeo mostrando em plano fechado botas que pisavam e destruíam margaridas).

No que diz respeito aos participantes, nós encontramos na conversa realizada com a linguagem cinematográfica uma distinção clássica entre participantes "conhecidos" (os membros da família, os amigos que estão no YouTube) e os desconhecidos. Aquele que publica um vídeo em uma rede pode escolher o público que quer atingir: limitá-lo a uma só pessoa, aos amigos, ou abri-lo a todo mundo. Tocamos, então, em uma diferença essencial entre conversa verbal e conversa pela linguagem cinematográfica: com a conversa verbal, o número de participantes é obrigatoriamente limitado, mesmo se outras pessoas podem acompanhá-la sem intervir (bystanders, espectadores); quando um vídeo é colocado nas redes sociais em livre acesso, o número de participantes atingidos pela conversa audiovisual é potencialmente ilimitado.

Vemos, em relação à conversa verbal, que a conversa audiovisual tem um funcionamento específico, mas o fato de ela poder existir representa a vitória da inscrição da linguagem cinematográfica no espaço da linguagem cotidiana. 


\section{Formas e funções da linguagem cinematográfica cotidiana}

A análise precedente desenha um processo de inscrição da linguagem cinematográfica em um espaço cotidiano cujas etapas podem ser resumidas em algumas palavras-chave: acessibilidade, competência ativa, disponibilidade, troca, interatividade, interação, conversa. Essas noções constroem o quadro no qual a linguagem cinematográfica intervém e determinam tanto a forma específica que ela toma nesse espaço quanto as funções que vão preenchê-lo. A análise dessas funções demandaria uma pesquisa sistemática sobre um corpus muito vasto, um trabalho que vai muito além dos limites desse artigo; me concentrarei sobre aquelas que me parecem mais novas.

É sem dúvida o caso da função instrumental. Certamente, os "filmes utilitários" (médicos, didáticos, científicos etc.) sempre existiram, mas eram feitos para funcionar em espaços dedicados, que não tinham nada de cotidiano; hoje em dia, a linguagem cinematográfica se tornou uma ferramenta colocada à disposição de todos na vida cotidiana. Dois usos se impõem: tomar notas e memorizar, e se informar (e informar). Podemos colocar quase qualquer dúvida em uma página de busca na internet e com certeza encontraremos imediatamente uma série de vídeos que respondem à questão colocada; todos os domínios da vida cotidiana estão cobertos: como fazer suas compras, cozinhar, perder um quilo por semana, se produzir, se vestir, cuidar do seu animal de estimação, dormir bem... e, evidentemente, a vida sexual. Mas, fato ainda mais notável, é que posso produzir eu mesmo vídeos instrumentais, enviá-los aos meus amigos ou acrescentá-los aos vídeos que já existem nos sites e nos fóruns de discussão.

Outras funções: a linguagem cinematográfica dá lugar aos atos de linguagem que funcionam sobre os eixos das relações interpessoais. Função de atestado: mostro um vídeo para provar o que digo ("é verdade, olha, havia uma coruja no meu jardim e ela girava sua cabeça em $360^{\circ \prime \prime}$ ). Função lúdica: dois garotos muito jovens brincam de se filmar mostrando músculos, inclinando o torso, fazendo caretas, em uma imitação dos combates que eles 
viram nos filmes ${ }^{10}$. Função de sedução: não é mais necessário ir ao cinema para conhecer alguém, é o cinema que vem até nós, ao menos temos no bolso uma ferramenta que permite começar uma conversa mostrando um vídeo. Função de agradecimento: enviar um vídeo aos recém-casados, no dia seguinte à cerimônia. Mas o uso mais frequente se relaciona com a função de socialização. Trata-se de confirmar o laço social com um grupo de amigos ou com essa ou aquela comunidade. Esses relacionamentos têm superado em muito as relações familiares.

O espaço das relações interpessoais está longe de ser sempre um espaço pacífico. Muitos vídeos confirmam isso (função polêmica): vídeos de provocação "eu a filmei porque ela não gosta muito de ser filmada, para incomodá-la e dei um grande zoom nela. [...] Na maior parte do tempo, é para incomodar as pessoas que eu faço os vídeos" (F., 18 anos apud BATIONO; ZOUINAR, 2009, p. 158) -; vídeos de assédio (publicados nas redes sociais, eles produzem muitas vezes situações dramáticas); conflitos por vídeos intercalados: a saga dos Lopez, que mostra dois clãs ciganos que dizem injúrias e se ameaçam por meio de vídeos intercalados, são um enorme sucesso na internet.

Há também, evidentemente, todos os vídeos de protesto. Estamos, nesse caso, na intersecção entre o espaço comum e o espaço social ou político. Da mesma maneira que não deixamos de ser cidadãos ao entrar no cinema ou ao assistir à televisão, como nos lembra Guillaume Soulez (2013), não deixamos nossa posição de cidadãos ao entrarmos no espaço comum. É por isso que inúmeros vídeos que tratam de problemas relevantes da vida cotidiana, mas também da política local - vídeos que mostram os problemas causados pelo novo plano de tráfego, contra o corte de árvores, contra o sistema de coleta de lixo implantado nessa ou naquela cidade etc. - até os da política nacional, como aqueles que denunciam a construção de uma linha de trem de grande velocidade, ou de um aeroporto. O limite entre o posicionamento do homem comum e aquele do cidadão (não falo 
do posicionamento do "militante", porque nesse caso, indubitavelmente, estamos em outro espaço) é geralmente bem difícil de traçar.

Outros atos de linguagem demonstram a autocomunicação: sentado em um banco, em um parque, filmo as crianças que brincam em minha frente, simplesmente para passar o tempo, porque eu não sei muito bem o que fazer; podemos falar da função passatempo ${ }^{11}$. Um passo a mais e publico meus vídeos; eles não mostram muita coisa de interessante, mas compartilhá-los me dá um sentimento de existir. Esse tipo de vídeo se prolifera nas redes. Enfim, filmar, no espaço cotidiano, serve a (se) construir uma identidade: nesse caso, os vídeos são pensados para mostrar essa identidade e, muitas vezes, revelam o íntimo. Serge Tisseron (2001, p. 52) explicou bem como o desejo de extimidade - "eu proponho chamar 'extimidade' o movimento que leva cada um a mostrar uma parte de sua vida íntima, tanto física quanto psíquica" - é apenas uma forma de o desejo "assumir melhor sua existência" (p. 59). A linguagem cinematográfica se tornou parte indissociável das "tecnologias de si" (ALLARD, 2014; FOUCAULT, 2001).

Para cumprir essas funções, a linguagem cinematográfica toma uma forma específica, uma forma adaptada a um espaço de comunicação cotidiana. Já que uma boa parte de sua história pode ser resumida pela conquista da homogeneidade (problema dos intertítulos) e por aquela da continuidade - problema da montagem: a célebre visual continuity, continuidade visual, defendida por Balázs (2010), hoje em dia, o que é mais recorrente no espaço cotidiano é a inscrição das sequências em linguagem cinematográfica em uma sucessão heterogênea de fragmentos originários de sistemas semióticos diferentes: uma mensagem em linguagem escrita introduz uma pequena sequência em linguagem cinematográfica, ela própria seguida de uma fotografia que dá lugar a uma troca em linguagem oral, que suscitará talvez uma nova intervenção em linguagem cinematográfica. Última componente no espaço da comunicação cotidiana, é normal que a linguagem 
cinematográfica se articule com as linguagens que já eram utilizadas, dentre as quais muitas já eram heterogêneas (a linguagem oral, por exemplo, é um misto de verbal, de gestual e de proxêmico) e fragmentadas: o contexto cotidiano não permite, em geral, longas intervenções.

Inversamente, os fragmentos tirados da linguagem cinematográfica são, em geral, planos únicos. Dizer que no contexto cotidiano quase não temos tempo nem possibilidade de fazer uma montagem não me parece uma explicação suficiente; seria mais justo reconhecer que a situação nos coloca em uma condição em que rodar algo mais que apenas um plano parece inapropriado: no espaço cotidiano, apenas o fato de interromper uma gravação para trocar de ângulo é problemático. É uma questão de posicionamento: aquele que filma se sente na obrigação de dar conta da continuidade espacial e temporal do evento que ele mostra, porque ele próprio pertence a esse espaço e tem consciência desse pertencimento. A regra da "montagem proibida" de André Bazin ${ }^{12}$ encontra aqui sua aplicação mais justificada: "quando o essencial de um acontecimento depende de uma presença simultânea de dois ou mais fatores da ação, a montagem é proibida" (BAZIN, 1958, p. 127). É exatamente o que ocorre aqui: aquele que filma faz parte do sistema de inter-relações. De fato, toda saída do plano único é uma saída do espaço cotidiano.

A tentação é grande, então, de dizer que assistimos ao retorno da linguagem do cinema dos primeiros tempos. Penso, no entanto, que essa forma de descrever as coisas é inexata: ela negligencia o fato de que esses planos, ainda que únicos, muitas vezes mobilizam inúmeras conquistas da história da linguagem cinematográfica. Um exemplo, para explicar o que eu quero dizer. O plano mostra a cena clássica da visita dos netos à avó; com seu smartphone, o neto filme a acolhida na porta, com os abraços, ele se aproxima para dizer algumas palavras de boas-vindas, as trocas de gentileza. Depois, sem cortar, ele entra na casa e segue, em travelling, os visitantes até que eles se sentam na sala. Enfim, ainda sem cortes, ele faz 
uma panorâmica para mostrar a decoração do espaço. A sequência termina com um plano fechado sobre uma foto de família em preto e branco, pendurada na parede. Construção narrativa, movimentos de câmera complexos, é o triunfo do plano sequência e da montagem interna.

Quanto aos gifs e vines ${ }^{13}$, que funcionam no efeito de looping (em ciclo), podem parecer nos levar de volta à época do pré-cinema (zootrópio, praxinoscópio) e do Cinetoscópio (MANOVITCH, 2001), mas o tempo não é o mesmo de quando nos impressionávamos diante de uma simples repetição de movimento. Hoje em dia, a limitação de produzir uma sequência a partir de um número muito limitado de imagens é sobretudo encarada como uma incitação à inventividade; é necessário encontrar, no mundo, uma situação que se encaixe a esse tratamento (movimentos circulares: um carrossel brilhante, cheio de cores, que gira no meio da noite como um anel mágico; movimentos repetitivos: os jogos de luzes que cintilam sobre o rosto de uma mulher) ou brincar deliberadamente com a diferença entre a ação mostrada e o efeito de looping: uma queda de skate repetida seis vezes seguramente produz um efeito cômico.

O trabalho com o zoom conduz igualmente a figuras inovadoras, como aquela descrita por Laurent Jenny, em La vie esthétique:

Como de costume, me chamou a atenção a exibição pitoresca de uma desses mercados nova-iorquinos abertos dia e noite, administrados por paquistaneses, que oferecem um panorama heterogêneo de produtos, que vão desde as canetas até os buquês de flores. [...] Eu pego automaticamente meu celular... e sempre para ver mais, me pego entregue à mania da ampliação pelo zoom digital, e concentrado sobre os efeitos de transparência entre os cubos de gelo e os pedaços de abacaxi. O resultado, consultado imediatamente, me enche de espanto. O tema se tornou totalmente irreconhecível, dando lugar a uma indiscutível composição cubista, daquele período maravilhoso dos anos 1908-1912, em que Braque e Picasso rivalizavam à beira da abstração. [...] O conjunto dá a impressão de que formas e cores foram esmagadas em uma moldura que as abriga com dificuldade e da qual elas gostariam de escapar. (JENNY, 2013, p. 89-91) 
O que é novo é que esse prazer do jogo com a abstração é agora compartilhado por mais pessoas: "o que era uma prática refinada de esteta se tornou uma espécie de habitus democrático", nota, um pouco desiludido, Laurent Jenny (2013, p. 69).

Com o bastão de selfie, assistimos ao vivo ao trabalho criativo, quando vemos em detalhe o rosto daquele que o segura, os olhos espremidos de atenção, concentrado nos movimentos que ele faz para enquadrar. Filmando-se em plongée vertical, um casal dança; aquele que segura o bastão olha para o próprio bastão, a mulher olha para aquele que filma; o efeito produzido é marcante e nos faz perder nossas referências espaciais. Um grupo, disposto em triângulo, a ponta correspondendo ao celular, vira passo-a-passo em $360^{\circ}$, permitindo a descoberta de todo o espaço da magnífica praça da renascença italiana, no meio da qual ele se encontra.

Ainda mais inovador: em inúmeras trocas, vemos a mobilização de uma combinação de dispositivos. Um exemplo: tudo começa com um diálogo por Skype entre um casal um pouco mais velho (os avós) e um casal jovem; depois de um tempo, "eu vou te mostrar uma coisa", diz a voz do homem mais jovem. Em seguida, sem cortes, o celular vira para a tela de uma televisão que se encontra na sala e na qual aparece, em poucos instantes, um vídeo onde vemos uma criança bem nova, que começa a andar; escutamos a voz dos avós visivelmente emocionados: "são seus primeiros passos?"; o avô expressa, em seguida, seu arrependimento por não poder falar com Laleh, que não estava ali: "não tem problema", diz a jovem, que tira seu celular do bolso e liga para Laleh; os avós veem então Laleh aparecer no telefone da mulher mais jovem, que é também em ligação pelo Skype e que filma o telefone de seu marido... Essa situação me foi contada por uma estudante iraniana como uma prática habitual em sua família.

Como vemos, tudo isso demonstra uma verdadeira criatividade na utilização cotidiana da linguagem cinematográfica; os leitores de Michel Maffesoli (1979) ou de Michel de Certeau (1980) não estarão surpresos, nem aqueles de Donald Winnicott (1988): essas pequenas "sequências" são o signo da nossa aptidão a "viver criativamente", isto é, de conservar ao longo da vida alguma coisa que faz parte da experiência da primeira infância, o sentimento de ter a capacidade 
de criar o mundo. Podemos falar de criatividade transicional. Basta observar as pessoas agindo para se dar conta de que há uma espécie de entusiasmo alegre na forma como a linguagem cinematográfica recobre a vida cotidiana. A linguagem cinematográfica (se) explode.

\section{Considerações finais}

Desde que ela existe, a linguagem cinematográfica foi aplicada a espaços com formas e funções diferentes, mas pela primeira vez na sua história, adquire um novo status no centro da sociedade: ela passa a ser uma linguagem cotidiana de comunicação interpessoal (entre nós e os outros, entre nós e nós mesmos). De fato, ela adquire um status paralelo ao da língua; ela se articula, frequentemente, com a língua em inúmeras trocas, ao mesmo tempo que opera em um modo completamente diferente: a linguagem mostra pedaços do vivido, e "ter compreendido algo na ordem do vivido é obviamente não ter, à primeira vista, seu equivalente conceitual e linguístico" (COHEN-SÉAT, 1958, p. 137).

Em todo este texto, falei de linguagem cinematográfica. Penso, assim, que a linguagem cinematográfica continua a base de tudo que ocorre no universo audiovisual, quer se trate de produções em vídeo, digitais, na televisão, na internet ou nas comunicações via celular. As principais noções da linguagem cinematográfica - plano, enquadramento, montagem, relação imagem-som (in, off, over) - sempre asseguram a estruturação fundamental, mesmo que, certamente, ocorram transformações (toda linguagem evolui) ${ }^{14}$.

Como vimos, essas transformações não constituem uma mudança de natureza: é a associação do celular ao digital e à internet que permite à linguagem cinematográfica de se tornar uma linguagem de troca e de conversa e, então, de se apropriar do espaço da comunicação cotidiana. No entanto, é um fenômeno muito raro ver uma linguagem mudar de status. Guardadas as proporções, essa mudança se assemelha ao que ocorreu quando a escrita foi adicionada à comunicação oral; 
mas, aqui, o movimento é de certa maneira inverso: diante da linguagem do espaço cinema, as produções do espaço cotidiano constituem um exemplo desse "cinema oral", teorizado por Germain Lacasse (2000, 2006, 2007), que se caracteriza por uma situação comunicacional com um Sujeito que se exprime aqui e agora. É evidente que essa referência ao oral é metafórica, mas ela é esclarecedora, porque nos conduz a fazer as mesmas perguntas que aquelas formuladas por Jacques Goody (1979) em La raison graphique, que mostravam as transformações produzidas pela passagem à escrita no nível cognitivo (desenvolvimento do pensamento lógico, da abstração, da categorização), psicológico e social (transformação das representações que uma pessoa ou um grupo tem do mundo, do outro e de si mesmo) e, em síntese, antropológico. É interessante notar que, por volta dos anos 1960, Cohen-Séat (1958, p. 19) já elaborava questões similares: "o que a intervenção do cinema coloca em dúvida é [...] algumas categorias e algumas das modalidades fundamentais da nossa relação com o mundo". "O cinema propõe uma mudança na ordem do discurso, ao mesmo tempo que ele modifica algumas das modalidades principais da percepção e do julgamento" (p. 22). Poderíamos citar muitos outros trechos. Em uma perspectiva análoga, me parece que dificilmente podemos evitar, hoje em dia, nos perguntar o que será produzido a longo prazo, se ela continuará com o mesmo dinamismo, essa transformação da linguagem cinematográfica em uma linguagem de comunicação cotidiana (insisto: em uma linguagem utilizada no cotidiano por todos e por cada um para se comunicar com os outros e consigo mesmo). Resposta em algumas centenas de anos.

\section{Referências}

ALLARD, L. Express Yourself 3.0! Le mobile comme technologie pour soi et quelques autres entre double agir communicationnel et continuum disjonctif somatechnologique. In: ALLARD, L.; CRETON, L.; ODIN, R. (org.). Téléphone mobile et création. Paris: A. Colin, 2014. p. 139-162. 
BALÁZS, B. Early film theory. Visible man and The Spirit of Film. Nova York: Berghahn Books; Oxford: Screen, 2010.

BATIONO, A. ; ZOUINAR, M. Les usages amateurs de la vidéo sur téléphone mobile. Réseaux, Paris, n. 156, p. 141-164, 2009.

BAZIN, A. Montage interdit. In: BAZIN, A. Qu'est-ce que le cinéma ? Paris: Cerf, 1958. p. $117-130$.

BETTETINI, G. La conversazione audiovisiva. Problemi dell'enunciazione filmica e televisiva. Milão: Bompiani, 1984.

CASETTI, F.; ODIN, R. De la paléo à la néo-télévision. Communications, Paris, n॰51 p. 9-26, 1990.

COHEN-SÉAT, G. Essai sur les principes d'une philosophie du cinéma. Paris: PUF, 1958.

CRETON, L. Le marché du caméscope. Innovation et logique de développement. In: ODIN, R (org.). Le film de famille, usage privé, usage public. Paris: MéridiensKlincksieck, 1995. p. 191-206.

DE CERTEAU, M. L'invention du quotidien. Tome I : Arts de faire. Paris: 10/18: U.G.E., 1980.

DELAVAUD, G. L'art de la télévision. Histoire et esthétique de la dramatique télévisée (1950-1965). Bruxelas: de Boeck, 2006.

FERRARIS, M. T'es où ? Ontologie du téléphone mobile. Paris: Albin Michel, 2006.

FOUCAULT, M. Dits et ecrits 1976-1988. Paris: Gallimard, 2001. 
GAUDREAULT, A.; MARION, P. La fin du cinéma ? Un média en crise à l'ère du numérique. Paris: A. Colin, 2013.

GOODY, J. La raison graphique. La domestication de la pensée sauvage. Paris: Minuit, 1979.

GUNTHERT, A. L'image partagée. La photographie numérique. Paris: Textuel, 2015.

JENNY, L. La vie esthétique. Stases et flux. Verdier: Lagrasse, 2013.

KERBRAT-ORECCHIONI, C. La conversation. Paris: Seuil, 1996a.

KERBRAT-ORECCHIONI, C. Les interactions verbales. Paris: A. Colin, 1996b.

LACASSE, G. Intermédialité, deixis et politique. CiNéMAS, Paris, v. 10, n. 2-3, p. $85-104,2000$.

LACASSE, G. L'accent aigu du cinéma oral. In: STÉPHANE-ALBERT, B. (org.). Le cinéma au Québec : tradition et modernité. Montreal: Fides, 2006. p. 47-60.

LACASSE, G. Laissez passer pour une ouverture, ou la théorie du cinéma entre oralité et littérature. In: FROGER, M.; MÜLLER, J. (org.). Intermédialité et socialité. Münster: Nodus, 2007. p. 57-67.

MAFFESOLI, M. La Conquête du présent. Pour une sociologie de la vie quotidienne. Paris: PUF, 1979.

MANOVITCH, L. Language of new media. Cambridge: Mass: MIT Press, 2001. 
METZ, C. L'énonciation impersonnelle ou le site du film. Paris: Meridiens Klincksieck, 1991.

ODIN, R. Le langage cinématographique comme langage ordinaire. $H A L$, Paris, 2017. Disponível em: https://hal.archives-ouvertes.fr/hal-01654243. Acesso em: 10 ago. 2021.

ODIN, R. The mobile phone, cinema and archiving logic. In: GIORDANO, F.; PERRON, B. (org.). The archives, post-cinema and videogame between memory and the image of the present. Milão: Mimesis International, 2015. p. 51-60.

ODIN, R. Cinéma et téléphone portable. Approche sémio-pragmatique. In: CRETON, L.; JULLIER, L.; MOINE, R. (org.). Le cinéma en situation. Experiences et usages du film, Théorème 15. Paris: PSN, 2012a. p. 79-88.

ODIN, R. E giunta l'era dei linguaggio cinematografico. Bianco et Nero, Romsa, v. LXXI, n. 568, p. 7-17, 2010a.

ODIN, R. La question de l'amateur dans trois espaces de réalisation et de diffusion. Communications, Paris, nº 68, p. 47-83, 1999.

ODIN, R. Le film de famille dans I'institution familiale. In: ODIN, R. Le film de famille, usage privé, usage public. Paris: Méridiens-Klincksieck, 1995. p. 27-42.

ODIN, R. Questions posées à la théorie du cinéma par les films tournés sur téléphone portable. In: CASETTI, F.; GAINES, J. Dall inizio, alla fine. Teorie del cinema in prospettiva. Udine: Presses Universitaires d'Udine: Forum Udine, 2010b. p. $363-373$. 
ODIN, R. Spectator, film and the mobile phone. In: CHRISTIE, I. Audiences. Defining and researching screen entertainment reception. Amsterdam: Amsterdam University Press, 2012b. p. 155-169.

ODIN, R. Les espaces de communication. Introduction à la sémio-pragmatique. Grenoble: PUG, 2011.

PEREC, G. Approche de quoi. In: PEREC, G. Le pourrissement des sociétés. Paris: Cause commune, 1975. p. 251-255.

SAPIO, G. La pratique des home movies. Culture audiovisuelle et genèse de la méta-famille. Tese (Doutorado em Estudos Cinematográficos) - Université de Paris III - Sorbonne Nouvelle, Paris, 2015.

SCHEFER, J.-L. L'homme ordinaire au cinéma. Paris: Cahiers du Cinéma: Gallimard, 1980.

SOULEZ, G. La délibération des images. Vers une nouvelle pragmatique du cinéma et de I'audioviduel. Communication \& langages, Paris, n. 176, p. 3-32, 2013.

TISSERON, S. L'intimité surexposée. Paris: Hachette, 2001.

WINNICOTT, D. Conversations ordinaires. Paris: Gallimard, 1988.

submetido em: 1 set. 2021 | aprovado em: 15 set. 2021 